\title{
Subarachnoid hemorrhage caused by rupture of Galenic vein malformation
}

\section{Subarahnoidalno krvarenje uzrokovano rupturom malformisane vene Galeni}

Mirela F. Jukovic, Katarina Gvozdenovic, Dalibor Ilic, Dragan Andjelic

RECEIVED 03.11.2015.

ACCEPTED 12.04.2016.

\section{ABSTRACT}

Vein of Galen malformation is uncommon cerebrovascular anomaly. Rupture of this anomaly in adults is usually represented as intracranial bleeding. We present 71 year-old men with sudden headache and loss of consciousness caused by rupture of vein of Galen malformation.

Key words: vein of Galen malformations; intracranial hemorrhages; tomography, $\mathrm{x}$-ray computed; angiography; adult.
Mirela F Juković, Katarina Gvozdenović, Dalibor Ilić, Dragan Andjelić

1. Centar za radiologiju, Klinički centar Vojvodine, Novi Sad

PRIMLJEN 03.11.2015.

PRIHVAĆEN 12.04.2016.

\section{APSTRAKT}

Malformacija centralne vene (vene Galeni) nije česta cerebrovaskularna anomalija. Ruptura ove anomalije u odraslih se obično prezentuje intrakranijalnim krvarenjem. Prikazujemo slučaj 71-godišnjeg muškarca sa iznenadnom glavoboljom i znacima gubitka svesti uzrokovanih rupturom malformacije vene Galeni.

Ključne reči: malformacija Galenove vene; intrakranijalno krvarenje; tomografija, X-zracima kompjuterizovana; angiografija; odrastao. 


\section{INTRODUCTION}

Anomaly of vein Galeni was described first time in 19 century by Steinheil as „varix aneurysm“ ${ }^{1,2}$.This type of vascular intracranial abnormality is rare, and takes about $1 \%$ in all intracranial cerebral vascular lesions. Lesions predominantly occur in children as developmental abnormality, but it could be found in any period of life ${ }^{3,4}$. According to Yasargil this malformation are classified into four types, where types 1,2,3 are fistulous communication between vein of Galen and arteriovenous (AV) malformation, but type 4 is parenchymal $\mathrm{AV}$ malformation which drain blood into vein of Galen ${ }^{5}$. Lasjaunias et al. introduced two types of this anomaly as choroid and mural types ${ }^{6}$. Clinical presentation of Galenic malformation is different in neonatal period, infancy and in older children and adults. A variety of symptoms and signs appear in the form of cardiorespiratory difficulties, seizure, hydrocephalus, headache, developmental delay, focal neurological deficit or intracranial hemorrhage $2,7,8$ depending on the number of arteriovenous connection and venous outflow obstruction ${ }^{9}$.

\section{CASE REPORT}

The 71 year-old men came to Emergency department with sudden headache and loss of consciousness. Non contrast computed tomography (CT) and CT angiography (CTA) immediately were done on hospital admission that showed subarachnoid hemorrhage $(\mathrm{SAH})$ caused by rupture of Galenic vein malformation (Picture 1,2). There were not tonsillar herniation or intracerebral hemorrhage. Laboratory analysis showed low level of platelets; no other abnormality were found. After diagnostic procedure, patient was hospitalized at Neurosurgery Clinic. Because of possibility to re-bleed, patient was not surgically treated, but constantly monitored.

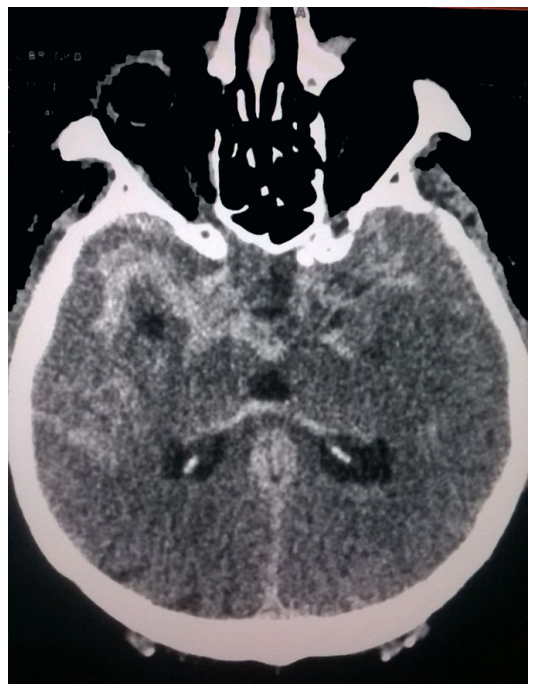

Figure 1. Non contrast brain CT scan showed subarachnoid hemorrhage in patient with Galenic vein malformation

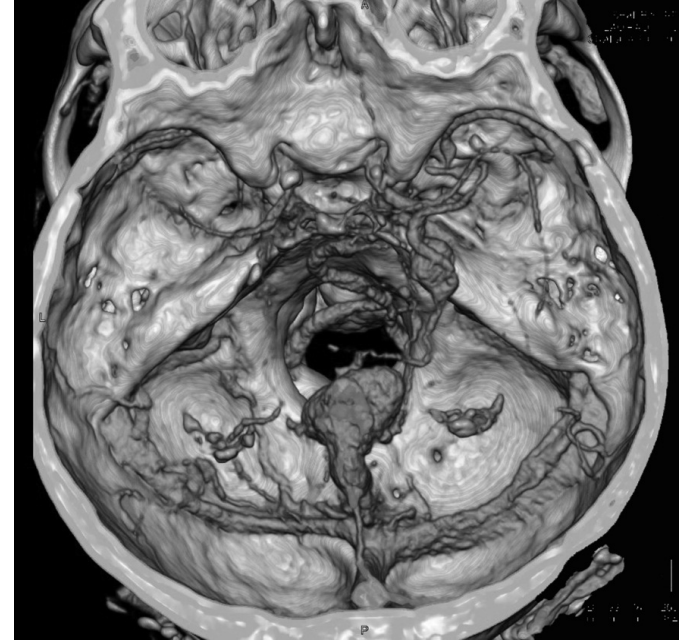

Figure 2. CT angiography showed vein of Galen malformation (VRT reconstruction)

During the hospitalization in the first and second day patient improved his clinical condition without neurological deterioration. Digital subtraction angiography (DSA) was done the next day and confirmed vein Galeni ectasia (diameter vein of Galeni about $30 \mathrm{~mm}$ ) with arteriovenous shunt, but without possibility to endovascular procedure (embolization) because of complex AV malformation, and probable complication during or after procedure such as increasing of vein pressure and massive intracranial hemorrhage. There was fistulous communication between external carotid artery branches and the right posterior cerebral artery (ACP). Patient had dilatation of extracranial blood vessels localized on the occipital part of the head under the skin as connection with both external carotid arteries. Control CT scan showed resorption of SAH and patients was discharged home after 10 days. Two years after initial examination patient had massive intracranial hemorrhage with poor clinical outcome.

\section{CONCLUSION}

Subarachnoid and intracerebral hemorrhage is more common in adult patients than children. Numerous of diagnostic procedure was implemented in daily routine practice. CT and CT angiography are very sensitive diagnostic methods for detection of intracranial hemorrhage and vascular anomalies and their application is useful in planning for surgical or endovascular treatment of patients ${ }^{2}$. In literature, this condition is the most challenging in a view of treatment, with high grade of poor outcome, especially in no treatable Galenic vein malformation ${ }^{8}$. 


\section{REFERENCES}

1. Ciricillo SF, Edwards MS, Schmidt KG, et al. Interventional neuroradiological management of vein of Galen malformations in the neonate. Neurosurgery 1990; 27: 22-8.

2. Gupta AK, Varma DR. Vein of Galen malformations: review. Neurol India 2004; 52: 43-53.

3. Marques RM, Lobão CAF, Sassaki VS, Aguiar LR. Vein of Galen aneurysm in adult. Arq Neuropsiquiatr 2006; 64: 862-64.

4. Jones BV, Ball WS, Tomsick TA, Millard J, Crone KR. Vein of Galen aneurysmal malformation: diagnosis and treatment of 13 children with extended clinical follow-up. AJNR 2002; 23: 1717-24.

5. Lasjaunias P, Ter Brugge K, Ibor LL, et al. The role of dural anomalies in vein of Galen aneurysms: report of six cases and review of the literature. AJNR 1987; 8: 185-92.

6. Yasargil MG. Microneurosurgery IIIB. New York: Thieme Medical Publishers, 1988.

7. Bhattacharya JJ, Thammaroj J. Vein of Galen malformations. J Neurol Neurosurg Psychiatry 2003; 74: 42-4.

8. Gailloud P, O’Riordan DP, Burger I, et al. Diagnosis and management of vein of Galen aneurysmal malformations. J Perinatol 2005; 25: 542-51.

9. Scott WA. Magnetic resonance imaging of the brain and spine. 3rd ed. Philadelphia: Lippincott Williams \&Wilkins, 2002. 